\title{
JACK LONDON, THE SOCIALIST DREAM OF A YOUNG POET
}

\author{
JESÚS ISAÍAS GÓMEZ LÓPEZ \\ Universidad de Almería \\ jesuias@gmail.com
}

Received 11 June 2020

Accepted 3 November 2020

\section{KEYWORDS:}

Jack London; The Iron Heel; young poet; "Effusion"; "The Socialist Dream"; Martin Eden; "The Worker and the Tramp"; socialist ideal; existentialism.

\section{PALABRAS CLAVE:}

Jack London; El talón de hierro; joven poeta; "Efusión"; "El sueño socialista"; Martin Eden; "El obrero y el vagabundo"; ideal socialista; existencialismo.

\begin{abstract}
Jack London began writing poetry in May 1897. From then on, the lyrical process, in the form of odd, single lines, stanzas and complete poems, would be present throughout his career as a novelist, essayist and short-story writer. His most ambitiously prolific period was between 1897 and 1899, and by the age of twenty-three he had already composed and published most of his poems. London's incursion into poetry was not fortuitous, but instead was a deliberate, personal decision to enter what he hoped would be a lucrative profession. This began in May 1897, with the poem "Effusion", which launched what was to be a short but vibrant poetic career. London's poetry is replete with a wide variety of issues and captures the most intimate and existential expression of a young man who aspired to make poetry the literary and vocational tool with which to become a crucial figure in the promising socialist movement of the fin de siècle. RESUMEN

Jack London empieza a escribir poesía en mayo de 1897. Desde entonces, el proceso lírico, mediante versos sueltos, estrofas y poemas completos, estará presente a lo largo y ancho de su carrera como novelista, ensayista y autor de relato corto. El London más comprometido con la poesía lo encontramos entre 1897 y 1899,
\end{abstract}


cuando, a los veintitrés años, ya ha compuesto y publicado la mayoría de sus poemas. La incursión de London en la poesía no es fortuita, sino fruto de una decisión personal, como apuesta profesional, cuando en mayo de 1897 compone el poema "Effusion", que inicia su corta, aunque vibrante carrera poética. En la poesía de London se advierten la diversidad de asuntos nacidos del plano más íntimo y existencial de un joven poeta que aspira a hacer de la poesía la herramienta literaria y vocacional con la que convertirse en una figura crucial del promisorio ideal socialista del fin de siècle.

\section{INTRODUCTION}

In 1913, Jack London stated in his one-act verse play, The First Poet: "It is a vain thing to make songs of the stars, that seem scornful even of me; or of the moon, which is never two nights the same" (Wichlan 194). This reflection sums up the poetic intention of the brief but explosive lyrical process of a young London who, already a renowned writer of fiction and almost fifteen years after penning his first poems, revealed to the reader what he saw as the keys to avoiding poetic failure, which could also be extrapolated to his fiction: "I do give my mind solely to the care of my hunting-gear" (Wichlan 195). In this case, "hunting" had nothing to do with chasing animals, and instead was telluric and mineral, as can be seen in his poem "The Klondyker's Dream", a tragic ballad that echoes Coleridge's "The Rime of the Ancient Mariner", in which the lyrical agent is in turn the lyrical voice of this and other poems by London. These include "He Never Tried Again" and "The Socialist Dream", set against the backdrop of the Klondike Gold Rush, in the last decade of the 19th century, when thousands of gold-diggers, including London himself, descended on the Yukon region in northern Canada. This is how the young poet became one of the "Klondykers" who "raged on in wild pursuit of Gold" (Wichlan 33). Like so many others, he returned empty-handed as recounted in his poem "He Never Tried Again": "And starved and frozen he returned, / singing a sad refrain" (Wichlan 37). The hunt for gold is an ever-present leitmotif in London's poetry, a central theme that oscillates between the dreams and nightmares, the glory and hell, the ideals and dramas of this young twenty-two year old poet who, a year 
after succumbing to gold fever, ${ }^{1}$ did poetic justice to a physical and spiritual suffering that would later help him recognize, locate and hunt down his most intimate demons: "It was in the Klondike that I found myself" (Kershaw 146).

Of all of London's vast literary production, The Iron Heel, published in 1908, is one of "his most revealing books" (Kershaw 333), and according to London himself, "in many ways, the most daring book I have ever attempted" (Labor 239). It was one of the first political dystopias of the $20^{\text {th }}$ century. By then, London was already one of the most widely read authors in the United States and in Europe. London's poetry, however, his original literary vocation, would go completely unnoticed by readers and critics until 2007, when the publisher Daniel J. Wichlan decided to compile all of Jack London's poetic oeuvre in The Complete Poetry of Jack London, a volume that brings together all the different stages of his work as a poet, from the publication of his first poems in various magazines in 1897 to the last ones attributed to him, which date from around 1915. London seems to have written his first poems in May 1897 (Wichlan 15), when he was twenty-one; but as Wichlan warns, his passion for poetry must have been instilled in him as a child, when at the age of ten he established a close disciple/mentor relationship with Ina Coolbrith, a librarian at the Oakland Free Public Library in California, creating an influential bond that would last a lifetime (Wichlan xv).

This short introduction to the young Jack London sets the tone for the primary purpose of this paper, namely to highlight the significant role played by poetry in the early stages of his literary career. To this end, we will begin by exploring to what extent London used his poetic art to articulate his early political views and his future career as a novelist. We will also see how poetry, London's first literary manifesto, becomes a powerful artifact for fighting the prevailing social injustice of his day, an idealistic vehicle with which to express his socialist ideals, so contributing to what he hopes will be a just future society, peopled by a better humankind. Later, we will be observing the change of heart in London's poetry, as his idealistic socialism gives way to an existentialist horizon in which religion, love and suicide presage the success of his later career and the final tragedy of his brief but intense life.

\footnotetext{
${ }^{1}$ London left for Alaska on 25 July 1897 and returned on 22 June the following year, poorer than when he left; but, as Labor admits, "infinitely richer in experience" (Labor 175).
} 


\section{THE POETICS OF A SOCIALIST DREAM}

Jack London was a man of many artistic passions, as he later confessed in his autobiographical novel John Barleycorn (1913): “(in January 1897) I had four preferences: first, music; second, poetry; third, the writing of philosophic, economic, and political essays; and, fourth, and last, and least, fiction writing" (220-221). London's most ambitious spell as a poet ran from 1897-1899. He completed his first six poems, including "The Socialist Dream", in May 1897, and composed and published most of his other poetic offerings, as well as more than sixty short stories in the next, very intense, two years. As Earle Labor states, "London was not yet a literary celebrity in 1899 , but he was a published author" (Labor 237). His short stories and poems appeared in renowned literary magazines such as The Black Cat, The Owl, and the Overland Monthly (Labor 231). Despite this, his poetry was far from lucrative and it seems that the few poems for which he was paid were later never published. London won $\$ 10$ for one of two poems he submitted to a contest sponsored by the American Republican Party in 1899, although it is unclear whether the prizewinner was "Republican Battle-Hymn" or "Republican Rallying Song", (Wichlan 44-45). Fortunately for London, although they were not his first choice as a writer, he was well-rewarded for almost all his stories and essays.

In fact, as the world entered the 20th century, music and poetry remained the young writer's main priorities, even though his prose was in higher demand. London, who had no musical training, did not play or compose music and instead viewed it as a sort of personal ars poetica in which he would provide verse and theatre with a certain musicality about them, while at the same time engraving upon them a strongly lyrical air, as can be seen in his plays The Acorn Planter and The First Poet, the latter composed in collaboration with the American poet George Sterling, a close friend of London's at the time, who would have a great influence on his initial literary endeavours (Wichlan 132, $152,383)$. The parade of ballads, stanzas, couplets and choruses in these plays enables them to be interpreted as musical comedies, a quality which, as Wichlan remarks, "demonstrates the fungibility of song and poetry in London's mind" (Wichlan 131). This association of genres would become, as we shall see, a distinctive trait of much of 
his poetry, because, as Wichlan states, "poetry and song seem to be intertwined in the London psyche" (xviii).

London embarked on his poetic career at the age of twenty-one with "Effusion," composed in May 1897. He was unable to find a magazine that would publish it, so he decided to include it in his short story "Nothing that Ever Came to Anything," the fourth of the eight stories that make up The Human Drift, published posthumously in February 1917. In the poem, the narrator urges the recipient of his poem, Mabel Applegarth, ${ }^{2}$ who was also the poet's first and greatest love, to abandon him to his fate in a kind of poetic drift: "Leave me to my fate" (Wichlan 2), aware that she, like her family and circles of friends, wanted him to abandon his literary dreams in search of a more conventional, more stable profession (Labor 311 ). The poem contains a lyrical modality that starts with a rebuke to his lover for turning the long affliction of her beloved poet into the cause of his suffering: "Thou canst not weep" (Wichlan 2). The fond memories of the intense passion they had once shared are transmitted through this modalization: "The mystic chains that bound / Thy all-fond heart to mine", and finally truncated: "Alas! asundered are / for now and for all time" (2). The lyrical modality culminates in a resounding, pessimistic vision of the poetic future of this lyrical subject, which presages a reunion with his beloved only after both have died: "Our souls must need unite-/ But, God! 'twill be too late" (311). The expression "too late" would become an explicit and revealing poetic leitmotiv in London's verse, which, as we shall see in his poetry, cropped up again and again in some of his pivotal poems. The poem's coda is infected with pessimism, with a melancholic tone that suggests the author was in the midst of one of his frequent depressive phases, and somehow anticipates the existentialist tragedy of his own life, constantly surrounded by the idea of death as a liberating image. The poem, therefore, as its very name indicates, represents the "effusion" of the lyrical subject's spirit, which is subordinated to a progression of the rhythm of thought that ends up being diluted in a frustrating fatalism provoked by the selfcondemning sentence: " "twill be too late" (2).

London's next poem, "The Mammon Worshippers", was also written in May 1897, although it was not published until long after his

\footnotetext{
${ }^{2}$ Mabel Maude Applegarth (1873-1915) was from a well-to-do British family, and had received a firstclass education. She was the social antithesis of London, who was of poor extraction. The class differences and the aesthetic discrepancies between the two could not prevent an intense three-year love affair between them from 1895 to 1898 (Raskin 32; Labor 211).
} 
death in The Saturday Evening Post, on 25 December 1976 (Wichlan 3). In 1898 he inserted it (as the epigraph) into his short story "The Devil's Dice Box" (Labor, The Letters of Jack London 37), itself part of A Klondike Trilogy: Three Uncollected Stories (London 17). In this poem, the lyrical subject establishes a narrative rhythm which, although it slows down the poetic rhythm, advances the sound timbre effectively. This is achieved by means of a long, well-structured, syllabic versification with verses divided by a caesura into two hemispheres, which, in passing, evoke the capital features of Anglo-Saxon verse: "We worshipped at alien altars; we bowed our heads in the dust" (Wichlan 3). Although London uses this resource of quantitative metrics to take the poem back to a long-gone ancestral era, as a hybridisation of Greco-Latin and Anglo-Saxon traditions, it nevertheless remains true to the syllabic-actual meter of the foot par excellence of modern English verse, the iambic pattern. This ingenious combination of meter, rhythm and rhyme bestows on the poem its historical, sacred tone and denotes the wise resolution of a young poet. In just four verses, he relinquished the first person perspective to prioritize the drama of an episode from the Old Testament ("We worshipped at alien altars") addressed to all humankind, a group that also included the lyrical subject himself, and which presaged his being damned "to the pit of hell" (3).

As we can see, optimism is not a feature of London's poetic beginnings. However, in his next poem, "Daybreak," which he wrote in July of the same year, the discourse has a new, much more connotative, evaluative register, in which the personal, fluid, discourse concludes in a witty, humorous internal dialogue when the poet receives an unexpected reply from his beautiful, anonymous addressee: "No, never mind, leave your own can, / And put two quarts, please, in it" (4). In a letter to his friend Edward Applegarth (brother of Mabel Applegarth) on September 15, London explained that this poem, together with "Hors de Saison" and "Je Ris Espoir" "were experiments in feminine endings" (Wichlan 4). This poem, which takes the form of a classical four-line verse ballad, begins with a bucolic scene that tends more to evoke and describe than to narrate: "The blushing dawn the easy illumes, / The birds their merry matins sing" (Wichlan 4), a feature that contradicts the poet's intention, in that it anticipates a lyrical attitude in which words prevail over ideas and, therefore, the musicality of the verse prevails over linguistic experimentation: "The buds breath forth their sweet perfumes, / And butterflies are on the wing" (4). It is undoubtedly a youthful poem, where language is closely 
integrated into the placid, bucolic environment in which the scene is set: "Ye Gods! in my imagination, / the wondrous scene do I behold / A nymph's bewildered consternation" (4). Although, as previously noted, the poem does not seem to be a highly developed "linguistic experiment", it does create a clear visual impression with the recurring images of an ardent spring morning portrayed by a girl "fair as the morn, with rosy light" (4), images that function as part of the line of thought of the sentimental lyrical speaker: "Then I see / [...] sweet eyes beaming down on me" (4). The hoped-for "linguistic experiment" has not matured, but could perhaps be considered in its early stages, insofar as the poet at least manages to unite language with the reality it represents.

Around the same time, London put pen to paper in "Gold", a lengthy poem with clear political connotations, marked by a lyrical dramatization in which gold is "the deadly drug to lure manhood away" (28). He wrote the poem shortly before his expedition to the Klondike, on his own unsuccessful hunt for gold. A year later, on September 15, 1898, in a letter to his friend Edward Applegarth he would describe this trip as his "first \& only flight" (29), as well as confirming his interest in the use of poetry as linguistic experimentation: "You will see that I attempted an improvement on the 'Spenserian Stanza' by adding a second iambic hexameter verse" (29). However, scholars like Adams view the Spenserian aesthetics of the poem as a way of disguising the young poet's socialist ideals: "It is apparently an attempt to find a 'non-propagandistic' mode of expressing his socialist ideology" (Adams 227). Later that year, on November 27, 1898, London confessed in a letter to Mabel Applegarth his early disenchantment with the excessively pretentious result of the poem: "I treated my theme as Dryden or Thompson would have treated it. My elephantine diction was super -I out-Johnsoned Johnson. I was a fool and no one to tell me" (Wichlan 29). Only a year had passed before London himself was dismissing the aesthetic and literary value of a poem which, in spite of this, was still an ambitious rehearsal of verse rhythm, with regular successions of pauses flowing through intense iambic feet that marked off a melodic progression of phonic groups even in the most complex verses, as can be seen in the last two lines of each stanza, a technique best illustrated in the last couplet of the poem: "And stifling conscience yielding to covetous thirst / Seek thee and seeking fall degraded and accurst" (29).

May 1897 marked a transition in London's approach to poetry, when he wrote his first socialist literary manifesto, which he decided 
to issue in poetic form. The result was "The Socialist Dream", which despite being a manifesto was never published in London's lifetime, and only saw the light of day in 2007 in Daniel J. Wichlan's compilation. This poem, which consists of thirteen stanzas in sextets, is London's longest political poem. It has an irregular metrical pattern, ordered in sixth rhyme ( $a b a b c c$, dedecc etc.), in which the last two lines of each stanza have the same rhyming ending. This unusual structure was a sign of the importance of form for London in what would be "his most explicitly socialist" poem (Adams 226). However, this excessive attention to form was paradoxically the reason why in the end London chose not to publish it, as is shown in the letter he wrote to his close friend Edward Applegarth, the following year, on September 15, 1898: “'Socialist Dream' was my first attempt to merely think in meter-full of errors" (Wichlan 34). Despite this harsh self-criticism on London's part, apart from being a valuable document that signals the development and literary progress of our author, the poem also offers an unusual portrait of the worker that was quite unlike any subsequent depiction in London's writings. The image that London usually offers of the worker in his fiction and essays is of someone that belongs to a disaffected part of society, who is mistreated by the government and by voracious Western capitalism. London explained his approach in a letter to his close friend Cloudesley Johns on June 16, 1900:

But God, man, handle them as they should be. Don't you tell the reader the philosophy of the road [...] But have your characters tell it by their deeds actions, talk, etc. Then, and not until then, are you writing fiction and not a sociological paper upon a certain substratum of society" (Hendricks and Shepard 107-108)

In the poem, however, the worker does not fight for his rights, nor does he seem to endure the same sufferings and injustices as his counterparts in London's fiction. Scholars such as Adams warn of this worker's "dishonest" attitude, insofar as he renounces his struggle as a social activist and revolutionary: "The worker is dishonest simply because he is a worker and a 'dreamer' rather than an activist trying to bring about the dreamed-of better world" (Adams 227).

In the few studies that mention "The Socialist Dream," we notice two contrasting positions: on the one hand, those who, like Wichlan, barely give it a passing glance, and, on the other, those who, like Adams, question its literary quality purely on the basis of its 
treatment of the socialist worker, who in his opinion is "unorthodox" (Adams 227). However, both scholars overlook other noteworthy elements of the poem which would have enabled them to offer a bettergrounded, more objective assessment of it. Both Wichlan and Adams choose to focus purely on the poem's political message, without realizing that much of its value lies in the sonorous, rhetorical, connotative and narrative qualities of the poem. Other scholars from a different critical tradition contend that these qualities also express meaning. Along these lines, for example, the American poet, Archibald MacLeish, argued that "the structure of meanings which the reason cannot find - or can find only to destroy - exists in the emotions" (MacLeish 46). Following this interpretative line, "The Socialist Dream" presents, without doubt, a compendium of lyrical dramatism in which the poetic voice, the socialist worker and "dreamer," assumes the role of a third-person narrator, who is happy to inhabit the world of the just: "He saw the soil enriched by men, / Who gloried in such honest life," as opposed to the tempestuous, dark atmosphere surrounding the capitalist tyrant who opens the poem: "The room was narrow and cold and grim; / He reigned supreme, a king of dirt" (Wichlan 32).

However, the main virtue of the poem lies in the lyrical monologue to which London resorts throughout the poem. This internal focalization enables the reader or listener to approach the poem from the point of view of an unusual, unique character who, more than a "dreamer", considers himself to be a kind of messianic utopian of the socialist ideal: "The vision fair, before him shone; / His heart in ecstasies was rapt; / He awoke - he was no more alone" (33). But his "visionary" quality proves short-lived. When his landlady comes to demand the rent, he finds refuge in lies: "The socialist, in accents mild, / Told her a lie upon the spot" (33). He then adds a dose of sarcasm, where the comic note somehow atones for the narrator's less than utopian behaviour: "His aunt had died; / the bells had tolled; / His was the money; hers the mould" (33). This kind of black, cynical humour culminates in the speaker's emotional and idealistic blindness, when he casts aside any remaining scruples and renounces his ideals to persuade, by telling an even "greater lie" to a poor, hardworking friend of his to lend him some money: "Then hied him to a labouring man- / Forgotten was his vision pure- / Whose hand was rough and face was wan, / And did a greater lie conjure" (33). However, this degrading "vision" of the socialist worker should not be interpreted as a criticism of socialism, but rather as a warning about the fickle nature of every human being, who faced with material need 
or temptation may give up his socialist, humanist ideal -in this case: "Tis thus with all poor mortals here, / Whose dual natures struggles wage" (34). The poet himself had already fallen victim to such "temptation" two years earlier, in his vain hunt for gold in the remote Canadian region of the Klondike, as he reminded himself in the concluding lines of the poem: "And with their passions uncontrolled, / Rage on in wild pursuit of gold" (34). It is clear that the involvement of the poet in the poem is emotional, and therefore moral, but also social and ultimately political.

Continuing with this theme of political poems with a socialist base, one year later in December 1898, London produced the poem "The Worker and the Tramp," which was published in October 1901 in The Comrade, New York (Wichlan 5). In this piece London continued his exploration of pastoral poetry, this time resorting to what was then a new poetic form, the villanelle. While in "Effusion," mentioned earlier, the poet proposed an "essay of linguistic experimentation," in this piece he embarks on an experimental essay in the villanelle, which evidences London's search for new forms that can express his most imminent political and social concerns in a truer, more fluid way. By then, London was already an avowed, enthusiastic socialist as he had officially joined the Oakland Socialist Labor Party two years earlier, in April 1896 (Labor 83), and sought to use poetry as an expression of his social commitment. This likeable villanelle, apparently innocent in its festive tone, is undoubtedly London's finest political proclamation, a poem that scholars like George Adams rightly consider "the best of London's political poems" (Adams 226). This poem seems to anticipate the theme of much of London's subsequent literary work, in that both the title and the message announce the author's political commitment to socialism, which was also abundantly clear in future essays that developed this same idea. These included three short essays, namely "The Tramp" (1902), "How I Became a Socialist" (1904), "The Class Struggle" (1903), and a longer essay War of the Classes, published in 1905 (Kershaw 324-325). London uses the rhetorical figures of repetition that are characteristic to this poetic form, in which the line that opens the first stanza ("God keep you, friend!"), is repeated as the last line of the second and fourth stanzas. Likewise, the third line of the first stanza: "Here's a quarter to spend", is repeated as the last line of the third and fifth stanzas. The two refrains, "Heaven bless you, my friend" (Wichlan 5), and "Here's a quarter to spend" (5), are not used by the poet as simple ornaments of language, but as figures of thought. The first, by oblique allusion and exclamation, declares the "tramp" 
his "friend", and the second ("Here's a quarter to spend"), via the appellative function of language, highlights his willingness for dialogue, as present in the poetic attitude of the poet towards his addressee, the "tramp", even though the tramp does not reply. The benevolence with which the worker treats his silent interlocutor, the tramp, is an expression of his feelings for the most disadvantaged social classes. But the most interesting detail in this scene played by these two characters, one actively, and the other in a more passive role, lies in the fact that they are both powerful symbolic images of London himself who, at the time he composed the poem, had already experienced, of his own volition, what it meant to be a socialist worker and a tramp. Six years later, in 1907, London would offer a portrait and detailed study of the "tramp" in his autobiographical memoir The Road (1907), where he states: "He is the by-product of economic society" (London, The Road 69).

As Paul Durica aptly confirms, "by the end of the century, more and more Americans were 'enjoying' themselves by imagining themselves as some kind of wanderer" (Durica 472). And London was no exception, to the point of declaring himself a true "tramp-royal" (London, The Road 38, 100), a title that echoes the famous "Sestina of the Tramp-Royal" (1896) by Rudyard Kipling, a writer that London admired at that time, although his interest was later to wane. A few years later, London would confess his fascination with Kipling's poetic tempo, in particular with the poem "The Song of the Banjo", in a letter to his friend the journalist Cloudesley Johns in March 1899: "Kipling had a good hand with 'the barley Soul of Things' " (Hendricks and Shepard 22-23). With these historical and literary antecedents, also marked in the personal sphere, it seems only right that the empathy that the lyrical subject displays for the lyrical addressee should emerge within a very personal register of discourse. This gives rise to an aesthetic sensibility which is both colloquial and connotative of the healthy coexistence between two apparently opposed positions in life, which are, however, essentially united by a healthy approach to social adhesion. The worker recognizes that he is employed thanks to the unemployment of the tramp: "On you I depend / For my work, don't forget" (Wichlan 5). In this poem, London carries out one of the most daring experiments in the narrative field. The poem is written in the first person; but as George Adams states, "a first-person "protonarrative' that could easily be transformed into a third-person point of view" (Adams 226). 
Another poem that deserves special mention when describing London's political commitment is "Republican Battle-Hymn," written in October 1898, which, although devoid of the same force in terms of social activism, does add a new dimension and focus to the author's political vision, in this case more personal and humanistic, and freed from propagandist overtones: "An attempt to find a 'nonpropagandistic' mode of expressing his socialist ideology" (Adams 226). As we noted at the beginning of this essay, this is one of two poems that London sent to a contest organized by the Republican Party (Wichlan 45). The poem, which judging by its title seems to be a patriotic hymn to republican values, is in fact quite the opposite, a hymn of praise for the solidarity and union between all American political creeds: "Our country is far dearer / Than closer bonds of blood" (Wichlan 43). The poet's idealism does not have a political background here, and instead is humanistic and spiritual, demonstrating his unwavering social commitment: "When man calls man 'O brother!"'(43).

This rich diversity of registers of discourse confirms that London's early poetic endeavours were founded on his passionate socialist dream, an aesthetic judgment that constitutes one of the bravest poetic licenses of the fin de siècle.

\section{THE POETIC TURN TO EXISTENTIALISM}

But it is not only politics that London speaks of in his poetry, religion also drives the lyrical process of some of his poems. This can be seen for example in three poems worthy of special consideration, "A Heart," "The Song of the Flames" and "The Gift of God", which symbolize London's vision of religion, not as a simple dogma, but rather as a powerful, influential social bond. The first piece, "A Heart", was a long poem written in early 1899 that was never published. George Adams notes that the poem is reminiscent of "The Wayfarer" by Stephen Crane (Adams 228), which, incidentally, was written around the same time. It is true that in both cases the subjects are "walkers," but, in our opinion, they are exploring very distant paths and are driven by very different motives. If in Crane's poem, in just ten verses, one immediately grasps the difficult adventure on which the "wayfarer" has set out on his "pathway to truth," which in the end proves elusive: "Doubtless there are other roads" (Crane 85), in Jack London's poem, by contrast, we witness a vast poetic process of 106 
lines distributed in six irregular stanzas in which the poet establishes a monologue in which he represents the poet himself, in the guise of the two successive walkers, thus creating an atmosphere imbued with mystery and fantasy: "A lonely dwelling in a garden bowered, / far from the world, the haunts of busy men / It stood alone" (Wichlan 57). We thus witness the description of three poetic addressees: the steps of these two walkers, who in some way represent the poet himself, and the "dwelling," which stands as the final, unifying protagonist of the poem. We do agree, however, with Adams' assessment of the allegorical aspect of London's poem as a critique of the political structure of religion: "The poem is apparently an allegorical critique of organized religion versus the pure religion of Jesus" (228): "The shrine is cold and lifeless, and the house / No longer dreams of things to come" (Wichlan 59).

The next poem to discuss is "The Song of the Flames," which was written in 1899 and once again was never published. As Adams makes clear, as "obscure" as his previous offering (Adams 228), this poem deals first of all with the liberation of souls (in the form of sun sparks) from their earthly prison by the work and grace of God: "We are motes of sunshine stolen / When the world was fair and young" (60). The poet acts as a narrator conveying a message about the origin of humankind. His knowledge of the origin of humanity is so one-sided that he dares to offer a vision that is highly subjective due to his advanced beliefs, which are beyond doubt. For him "our second birth" is not to be interpreted as a "reincarnation", but rather as the passage from death to eternal life: "Till God, turning many pages, Deemed it fit to set us free," a quality that demonstrates the poet's faith in a promising afterlife: "Dreaming of the time to be" (60).

The next religiously-orientated poem we should consider, "The Gift of God", written on June 2, 1899, offers a foretaste of the existentialism that London went on to cultivate in his future novels and essays. In the poem, the poet resorts to lyrical narration with a narrative voice that identifies with the story being told by using direct speech within inverted commas. In this case the narrator implores listeners to tell him what they believe is God's most important gift: "Name me the gift of God!" (61). The poet establishes a clear distinction between two types of addressees that must answer such an existential question. On the one hand, all humanity, as a single mass united in a desperate cry that reveals the strength of desire and instinct above knowledge: "The strong ones became as one: / 'Life is the gift of God!" (61). And on the other, the second addressee, a single old man 
endowed with the wisdom drawn from his many years of life: "Then a greybeard, / Doddering on the edge of his grave" (61), who, with his dramatic, unexpected response, truncates the rhythm of thought of the scene. But the human mass, driven by a primary instinct to perpetuate the species, drowns out "his thin voice", thus showing its inability to interpret the true meaning of the response of the old man: "Death is the gift of God" (61), a poetic addressee whose response, although existential, reflects neither pessimism nor anguish, but rather a total freedom of choice, his own, after having seen, as a longlived spectator of the world, the true pathway and meaning of life: "He had seen three generations / come and go. / He knew all tricks" (61).

The pathway to existentialism also plays a prominent role in poems such as "When All the World Shouted My Name" and "He Never Tried Again." In "When All the World Shouted My Name" (of uncertain date), London directs his thoughts to a well-known lyrical addressee, "dear friend," a dear childhood friend whose name we do not know but whose memory is treasured by the poet: "You, who by closest bonds could claim / My memory?" (69). It is evident that London is using this unknown, close childhood friend of modest means as a counterbalance to his own life of popularity and fame. The life of both acquires a symbolic value, with different meanings and disparate consequences: "And, then - our paths did twist apart" (69). Their lives continued in opposite directions. While the poetic addressee leads a simple, quiet life ("You led your uneventful life"), the speaker pays the price of fame, being swept along in a permanent hectic bustle: "I trod the path / Of my own choosing - and alone" (69). The poet recognises in the simple life of his old childhood friend a more recommendable and healthy modus vivendi than his own: "The charm / Of life like yours I did not know" (69), to the point that in the penultimate stanza, in a moral tone of frustration, he establishes a symbolic image of strong expressive value to reflect on whether his life has been misspent: "A score of phantoms did I chase" (69). This visionary metaphor reflects London's frustration for a life wasted in a useless, absurd enterprise: "They were but phantoms, nothing more" (70). This same awareness of reality, after the resounding success achieved by the author, imbued with a profound existentialism, can be found in his most autobiographical novel, Martin Eden (1909), which at some point before its publication he thought of calling Success (Kershaw 369). Martin, London's alter ego in the novel, also experiences a similar epiphany when he suddenly discovers that his life has evaporated into glory and popularity: "He saw quite clearly that he was in the Valley of 
Shadows. His whole life was fading, withering away, heading for death" (Martin Eden 402). The "score of phantoms", as a visionary metaphor that expresses the poet's frustration, anticipates the same "Valley of Shadows" mentioned in the novel, as a sequence of images that in both works presage his final destiny-suicide.

In the second poem with an existentialist discourse, "He Never Tried Again," written on October 1, 1898, suicide appears as the culmination of all the adventures and misfortunes of a lyrical speaker whose every desire is frustrated. This leads the poet, from a narrative of intense internal focus, to resort to the first person to present a sentimental and subjective vision of the fateful direction his life had taken: "Naught could obstruct my course / ... / but therein lay the great mistake" (Wichlan 69-70). The theme of suicide-a frequent leitmotif in almost all of London's work-centres the narrative: "On Harlem Bridge he wept and wailed, / And leaped into the bay" (37). The attitude and response of the lyrical subject to the ingratitude of life gives the poem its title and reverberates throughout the poem, closing each stanza with a refrain designed to fix the main idea: "He never tried again." The poem consists of a regular meter in which the sound rhythm imprints a musical, emphatic style with forceful iambic tetrameters followed by iambic trimeters: "He heard the wondrous tale and went / to Klondyke's golden Shore." In this way, the sound dimension of the poem helps create an atmosphere of vitality in the first three stanzas, so revealing the lyrical subject's vital yearning in three major undertakings in his life: a materialistic urge, with his adventure in the "hunt for gold"; his commitment to his fellow man, as a soldier fighting for his country; and his amorous quest, aspiring to the love of a beautiful young woman. In all three he fails, much to his regret; hence the refrain-leitmotif, "He never tried again," is the path he undertakes, as a last resort and solution, to overcome each successive failure. Thus, in the final stanza, the same refrain-leitmotiv has ceased to be a personal option and is now a definitive, irrevocable condemnation, brimming with irony, in which fate is merciless in the face of his desperate attempt to prevent his own suicide. The final scene is infected with a double fatalism, when the thoughtful act of suicide is suddenly transformed into a kind of irresponsible fatal accident that can no longer be avoided: "He could not swim, so there he stayed - / He never tried again" (37), because it reveals the idea of suicide as one of London's most elaborate, frequently recurring poetical processes, as a glorious colophon for his literary career, as he 
confessed years later in his autobiographical John Barleycorn (1913), where suicide is the glorious end to all his previous failures:

Thoughts of suicide had never entered my head. And now that they entered, I thought it fine, a splendid culmination, a perfect rounding off of my short but exciting career [...] This was the trick of John Barleycorn, laying me by the heels of my imagination and in a drugdream dragging me to death (John Barleycorn, 115].

London wrote almost all his poetry in the decade around the turn of the twentieth century, prior to his later novels. It was a time when love was firmly to the fore. As George Adams makes clear, among the addressees of these poems, which deal both with sex and the female condition, there are five young women with whom London had some kind of love affair: Mabel Applegarth, Bess Maddern, Charmian Kittredge, Anna Strunsky and Blanche Partington (Adams 228). We will now focus on one of these, Anna Strunsky, the protagonist of the poem "A Passionate Author to His Love," undoubtedly, as we will see, the most ambitious and successful of London's love poems. The title of the poem mimics the famous "The Passionate Shepherd to His Love," by the Elizabethan poet and playwright Christopher Marlowe (1564-1593). The parody continues in the poem itself, which follows the structure, rhythm, meter and rhyme of Marlowe's pastoral poem. Both consist of six four-line stanzas in iambic tetrameters, with identical rhyme (aabb / ccdd / eeff / gghh / iijj / kkaa). The sonorous dimension is again important. Thus, we find an alliterative reiteration throughout the piece: "That furnace sighings, signed and sealed [...] I'd fly to thee / If from my fetters I were free" (Wichlan 18). In phraseological terms, we also appreciate the recurrence of rhetorical figures of speech such as the chorus which in both poems creates a stylistic effect of great depth. If in Marlowe's poem we notice the recurrence of "come live with me and be my love," which opens the first stanza, ends the fifth and brings the final stanza to a close, in this poem by London we find the repetition of another almost identical chorus, "Come write to me and be my Love" (18), which also opens the poem and brings it to a close in the last line. London makes only one change, replacing the verb "live" with "write," in a clear allusion to The Kempton-Wace Letters, the epistolary novel written jointly in 1903 by London and the young Anna Strunsky, with whom London had a long relationship with varying degrees of friendship and love over three decades (Labor 165-167). Although the novel itself is not about love, 
the poem continues along Marlowe's pastoral path towards love, with images that reinterpret the bucolic Renaissance-era setting, transporting it to a New World in which the beautiful rivers and sweet songs of Marlowe's birds have been replaced by "furnace sighings," "vows epistolary" and, above all, by the "millions" of dollars that the two lovers will earn with their "Love Letters of a Socialist" (18). But fate decreed that instead of London, Anna Strunsky would end up marrying William English Walling, a socialist millionaire, three years later. In the last stanza he promises his beloved a successful literary "business" in exchange for her love: "We'll turn our passion to account" (18). London never hid the fact that one of the most impelling reasons for devoting himself to writing was to obtain money and fame, which in turn brings in more money. However, as Labor warns us, London's obsession with money was to some extent an "ideal": "Money was a means to an end, never an end in itself. The concept was essential to the American Dream, inherited from the Puritan ethic" (134). London wrote the poem in 1904, by which time he had achieved the fame and economic success that he had so intensely pursued for years. Hence, this final stanza is full of irony in two senses, on the one hand the poet longs for "a large amount" of money that he already has and does not urgently need, and on the other, he seems to use this hypothetical "large amount" as a means of earning the approval of his addressee, even though both the poet and the addressee already know that this approval has already been granted, with or without this "large amount," in the form of unconditional, endless love (Labor 130-132).

During this creative period in the last decade of the nineteenth century, London clearly intended to make poetry the centre of his literary career. In the end however he received more gainful employment as a novelist and essayist. Although his love for poetry continued throughout his life, London did not pen many more poems of his own, and instead chose to include poems and stanzas by other authors as a vehicle for ideas in the construction of his novels and essays, as can be seen for example in the poem "The Challenge," by Henry Wadsworth Longfellow (1807-1882), at the end of Chapter 27 ("The Management") of his chronicle-essay The People of the Abyss (1903), and "Easter Day," by Oscar Wilde, which appears in Chapter 7 of The Iron Heel (1908), to name but a few. Although this poetry was not actually composed by London, it is a useful reminder that even many years after the composition of those first poems in the late nineteenth century, the internationally acclaimed novelist of the first and second decades of the twentieth century would never cease to 
think in poetic terms: "Prose and poetry were closely integrated in London's mind" (Wichlan xxii).

\section{CONCLUSION}

In this essay on London's poetry, I have sought to highlight the diversity and disparity of the issues discussed at this most intimate, most existential level of a young poet who aspires to make poetry the literary and vocational tool with which to become a crucial figure of the promising socialist ideal for the fin de siècle. London was aware of the strength and influence of socialism as a social discourse in the intellectual and artistic forums of his time. However, the reasons that led him to embark on a poetic career in May 1897, at the age of twentyone, were not only political. London was very aware, from the very first verse he wrote until his last creation, which appears in The Valley of the Moon (1913), that he was part of a well-defined cultural tradition in which religion and poetry still mattered: "Jesus, Lover of my soul, / Let me to Thy bosom fly, / While the nearer waters roll, / While the tempest still is nigh" (The Valley of the Moon, 375). Hence, in his lyrical processes he highlights his moment and place in history and within this tradition as a tangible fact and circumstance and not as a terrible storm through which to be dragged or annihilated. London's poetry is full of motifs and issues, some of which are fraught and existential, while others could be described as everyday issues, in which religion, society, love and history are explored as part of the young poet's attitude towards his culture, partly American and partly European, thus creating a youthful literary manifesto in the form of a lyrical collage, in which an apparently simple anecdote is capable of displaying the dramatism of more mature lyrical processes. Hence, in London's poetry, which is simple, direct and very personal, pessimism and optimism, the hilarious and the tragic, suicide and euphoria, sarcasm and praise, all seamlessly coexist as emotions and attitudes of a lyrical subject who knows that poetry creates its own world out of nothing, as can be noticed in "The Song of the Flames": "We are sparks of sunshine snatched away / when the world was young and beautiful" (Wichlan 60). And yes, although London is certainly a premature poet, who frequently resorts to poetry through an effective use of "the fourth dimension of the poem" (Abrams 2), to distil and filter many of the social and political themes that he would later give structure to and fully develop in his fiction, he is aware at all times that the poem is 
the ideal formula for frequently revealing the constellation of reflections or ideals that form the centrepiece of his particular universe and conception of the world, under a somewhat visionary prism of the socialist ideal, as he states in "The Socialist Dream:" "Beholding "mid a magic light / The fond utopia unrolled, / Of which the seers so often told" (Wichlan 33).

\section{WORKS CITED}

ABRAMS, M. H. The Fourth Dimension of a Poem and Other Essays. Norton, 2012.

ADAMS, George. "Jack London as Poet". The Oxford Handbook of Jack London, edited by Jay Williams, Oxford UP , 2017.

CRANE, Stephen. War Is Kind and Other Poems. Dover Thrift Editions, 1998.

DURICA, Paul. "The Ragged Edge of Nonentity". The Oxford Handbook of Jack London, edited by Jay Williams, Oxford UP, 2017.

HENDRICKS, King, and Irving Shepard, editors. Letters from Jack London, Maggibon \& Kee, 1966.

JOHNSTON, Paul. "The Fireside Poets". The Oxford Encyclopedia of American Literature, vol.11, edited by Jane Parini, Phillip Leininger, Oxford UP, 2004.

KERSHAW, Alex. Jack London: A Life. St. Martin’s Griffin, 1999.

KIPLING, Rudyard. The Seven Seas. Methuen and Co., 1914 (1896).

LABOR, Earle, Robert C. Leitz and Milo Shepherd, editors. The Letters of Jack London, vols. 1, 2, 3. Stanford UP, 1988.

---. Jack London, An American Life. Farrar, Straus and Giroux, 2013.

LONDON, Jack, A Klondike Trilogy: Three Uncollected Stories, edited by Earle Labor, Neville Publishing, 1983.

---. John Barleycorn. The Century Co., 1913.

---. Martin Eden. Macmillan, 1913. 
---. The Abysmal Brute. The Century Co., 1913.

---. The Human Drift. The Macmillan Company, 1917.

---. The Iron Heel. The Macmillan Company, 1908.

---. The People of the Abyss. Grosset and Dunlap, 1903.

---. The Road. The Macmillan Company, 1907.

---. The Valley of the Moon. The Macmillan Company, 1913.

---, and Anna Strunsky. The Kempton-Wace Letters. The Macmillan Company, 1903.

LONGFELlOW, H. W. Poems and Other Writings. The Library of America, 2000.

MACLEISH, Archibald. Poetry and Experience. Harmondsworth, 1960.

MARLOWE, Christopher. Complete Poems. Dover Thrift Editions, 2003.

RASKIN, Jonah. The Radical Jack London: Writings on War and Revolution. University of California Press, 2007.

STERLING, George. A Wine of Wizardry and Other Poems, A. M. Robertson, 1909.

WICHLAN, Daniel J., editor. The Complete Poetry of Jack London. Little Red Tree Publishing, 2014.

WILDE, Oscar. Complete Poetry, Oxford UP, 1997. 